\title{
KEBIJAKAN MORATORIUM PNS: \\ ANALISIS BEZETTING PEGAWAI, RIGHTSIZING KELEMBAGAAN, DAN BUDGETING PENYELENGGARAAN PEMERINTAHAN
}

\author{
THE CIVIL SERVANT MORATORIUM POLICY: \\ ANALYSIS OF THE EMPLOYEES BEZETTING, THE \\ RIGHTSIZING INSTITUTIONAL, AND THE BUDGETING \\ GOVERNMENT AGENCIES
}

\author{
Ajib Rakhmawanto \\ Pusat Pengkajian dan Penelitian Badan Kepegawaian Negara \\ Jl. Letjen Soetoyo 12 Cililitan Jakarta Timur \\ Telp. 021.80887011, 081310201165 \\ Email: ajib.bkn@gmail.com
}

Naskah diterima: 11 Agustus 2015, revisi pertama: 25 November 2015, revisi kedua: 25 Februari 2016.

\begin{abstract}
Professional civil servant management based on merit system is needed to support government's tasks. The arrangement on number, qualification, composition, and distribution of civil servants is required to rationalize civil servants'placement in order to improve their competencies and working performances. Moratorium policy is a temporary delay of civil servant recruitment to find out the actual employee needs based on the quantity and quality aspects. The goal of this study is to analyze the strategic issues to be used as recommendations in creating civil servant moratorium policy on some aspects, such as bezetting, organization rightsizing, business process, and the government budgeting. This study is a policy research using a qualitative descriptive approach, conducted with a Focus Group Discussion (FGD) method that produces primary data and documentation study that leads to secondary data. This study shows that civil servant moratorium policy is still relevant to be extended since it is viewed in the bezetting aspect: high number of employees is hired yet they are in poor quality. Then the organizational rightsizing is not conducted in a comprehensive structure particularly at regional government in which the business process is still far from ideal.The government budgeting is not ideal between employees' salary expenditure and development expenditure in which the composition of employees' salary expenditure is higher than the development expenditure.
\end{abstract}

Keywords: moratorium, bezetting, rightsizing, budgeting

Abstrak 
Pengelolaan PNS yang profesional berbasis merit diperlukan untuk menunjang kelancaran pelaksanaan tugas-tugas pemerintahan. Rasionalisasi penempatan PNS yang mengarah pada peningkatan kompetensi dan prestasi kerja memerlukan adanya penataan pada jumlah, kualifikasi, komposisi, dan distribusi. Kebijakan moratorium merupakan penundaan sementara penerimaan PNS untuk menciptakan kebutuhan riil dari sisi kuantitas maupun kualitas. Kajian ini menganalisis isu-isu strategis sebagai bahan rekomendasi untuk mengambil kebijakan moratorium PNS pada aspek bezetting pegawai, rightsizing kelembagaan dan tatalaksana, serta budgeting pemerintah. Kajian ini merupakan policy research dengan pendekatan deskriptif kualitatif menggunakan metode Focus Group Discussion(FGD) yang menghasilkan data primer dan studi dokumentasi yang menghasilkan data sekunder. Hasil kajian menunjukan bahwa moraturium PNS masih relevan dilanjutkan karena dilihat dari aspek bezetting pegawai secara kuantitas banyak tetapi secara kualitas sedikit, rightsizing kelembagaan belum menyeluruh khususnya pada pemerintah daerah dengan tatalaksana yang masih kurang sempurna, budgeting pemerintah belum ideal antara belanja pegawai dengan belanja pembangunan yang komposisinya lebih besar pada belanja pegawai.

Kata kunci: moratorium, bezetting, rightsizing, budgeting

\section{A. PENDAHULUAN}

Dalam rangka menunjang kelancaran pelaksanaan tugas pemerintah dan pembangunan dibidang SDM aparatur, diperlukan PNS yang profesional. Profesionalisme PNS terkait dengan kompetensi yang didalamnya terdapat penguasaan pengetahuan, keterampilan, dan perilaku dalam melaksanakan tugas pekerjaan. Upaya peningkatkan profesionalisme PNS memerlukan waktu dan proses panjang mulai dari rekrutmen, penempatan, dan pengembangan. Rasionalisasi penempatan PNSyang mengarah pada peningkatan kompetensi dan prestasi kerja, diperlukan adanya penataan PNS yang jelas dalam setiap instansi pemerintah. Proses ini merupakan siklus dari manajemen PNS yang tentunya menjadi perhatian bagi pemerintah, mengingat maju tidaknya PNS serta berhasil tidaknya instansi pemerintah sangat tergantung pada kompetensi PNS yang didukung dengan menyelenggarakan manajemen PNS secara profesional. Disisi lain perubahan lingkungan yang terjadi scara dinamis baik dari dalam maupun luar organisasi mensyaratkan adanya reformasi dalam praktek manajemen SDM PNS (Nurhaeni, 2012:47).

Penempatan PNS dalam instansi pemerintah sering menimbulkan permasalahan serius yang banyak menjadi perhatian publik dari berbagai kalangan. Persepsi yang sering dikritisi adalah terjadinya ketidakefektifan mengenai komposisi dan kualifikasi pegawai disetiap unit instansi pemerintahan. Pemetaan kebutuhan pegawai yang menyangkut jumlah/kuantitas maupun mutu/kualitas PNS tidak dilakukan secara proporsional. Kualitas pegawai yang diinginkan seharusnya sesuai dengan jenis pekerjaan atau jabatan serta persyaratan jabatan yang ada, sedangkan jumlah dan jenis pegawai yang dibutuhkan berdasarkan tingkat pendidikan atau keahliannya (Samsudin, 2006:62). Adanya ketidakseimbangan antara beban kerja dengan jumlah pegawai yang ditempatkan menjadi faktor utamanya. Instansi pemerintah jarang melakukan analisis beban kerja sebagai dasar untuk menyusun kebutuhan formasi dan penempatan PNS. Kondisi ini berdampak pada institusi seperti kekurangan atau kelebihan pegawai, kompetensi pegawai tidak sesuai jabatan, kurangnya pemahaman PNS terhadap tupoksi, pegawai tidak produktif, dan lain sebagainya. 
Pertumbuhan PNS di Indonesia diketahui bahwa dari tahun 2003 sampai dengan Desember 2013 mengalami peningkatan jumlah sebesar 714.800 orang dengan laju pertumbuhan rata-rata 1,64 persen. Pada tahun 2008-2009 terjadi kenaikan tertinggi yaitu mencapai 10,80 persen. Namun pada tahun 2010-2013 mengalami penurunan yang disebabkan adanya pensiun pegawai dan kebijakan moratorium pada tahun 2011-2012 yang lalu. Diketahui bahwa pertumbuhan jumlah PNS dari tahun 2003 sampai dengan Desember 2013 mengalami peningkatan jumlah sebesar 714.800 orang dengan laju pertumbuhan rata-rata 1,64 persen. Pada tahun 2008-2009 terjadi kenaikan tertinggi yaitu mencapai 10,80 persen, namun pada tahun 2010-2013 mengalami penurunan yang disebabkan adanya pensiun pegawai dan kebijakan moratorium pada tahun 2011-2012 yang lalu. Komposisi pertumbuhan jumlah PNS selama 10 tahun terakhir mulai dari tahun 2003 sampai 2014 dapat dilihat pada Tabel1.

Tabel 1.

Pertumbuhan Jumlah PNS

\begin{tabular}{|c|c|c|c|c|c|c|}
\hline \multirow{2}{*}{ No. } & \multirow{2}{*}{ Tahun } & \multicolumn{4}{|c|}{ Kedudukan PNS } & \multirow{2}{*}{ Jumlah } \\
\cline { 3 - 6 } & & Pusat & $\begin{array}{c}\text { Pertumbuhan } \\
(\%)\end{array}$ & Daerah & $\begin{array}{c}\text { Pertumbuhan } \\
(\%)\end{array}$ & \\
\hline 1 & 2003 & 840.007 & - & 2.807 .998 & - & 3.648 .005 \\
\hline 2 & 2004 & 804.547 & -4.2 & 2.782 .790 & -0.9 & 3.587 .337 \\
\hline 3 & 2005 & 850.442 & 5.7 & 2.811 .894 & 1.0 & 3.662 .336 \\
\hline 4 & 2006 & 764.305 & -10.1 & 2.960 .926 & 5.3 & 3.725 .231 \\
\hline 5 & 2007 & 772.864 & 1.1 & 3.294 .337 & 11.3 & 4.067 .201 \\
\hline 6 & 2008 & 760.923 & -1.5 & 3.322 .437 & 0.9 & 4.083 .360 \\
\hline 7 & 2009 & 906.658 & 19.2 & 3.617 .547 & 8.9 & 4.524 .205 \\
\hline 8 & 2010 & 937.784 & 3.4 & 3.660 .316 & 1.2 & 4.598 .100 \\
\hline 9 & 2011 & 925.848 & -1.3 & 3.644 .970 & -0.4 & 4.570 .818 \\
\hline 10 & 2012 & 910.939 & -1.6 & 3.557 .043 & -2.4 & 4.467 .982 \\
\hline 11 & 2013 & 891.509 & -2.1 & 3.471 .296 & -2.4 & 4.362 .805 \\
\hline 12 & 2014 & 902.543 & 1.2 & 3.472 .466 & 0.0 & 4.375 .009 \\
\hline
\end{tabular}

Sumber:Badan Kepegawaian Negara (2014:4).

Memperhatikan perkembangan reformasi birokrasi yang telah dilaksanakan sejak tahun 2006, kini telah memasuki fase gelombang kedua yang pelaksanaannya didasarkan padagrand design reformasi birokrasi Tahun 2010-2025 dan road map tahun 2010-2014. Roadmap reformasi birokrasi merupakan bentuk operasionalisasi grand design reformasi birokrasi yang disusun dan dilakukan setiap 5 (lima) tahun sekalidengan sasaran per tahun secara jelas. Sasaran tahun pertama akan menjadi dasar bagi sasaran tahun berikutnya, begitupun sasaran tahun-tahun berikutnya mengacu pada sasaran tahun sebelumnya. Ini merupakan upaya untuk perwujudan efisiensi dan efektifitas birokrasi serta mengoptimalkan kinerja PNS dalam meningkatkan pelayanan kepada masyarakat (public service). Peningkatan pelayanan publik yang berkualitas akan mendorong kepercayaan masyarakat pada pemerintah (Darto, 2014:24). Pada tingkat makro program reformasi secara umum mencakup pada tiga aspek, yaitu kelembagaan (organization), tatalaksana (business process), 
dan peningkatan kualitas PNS (human capital) melalui penataan sistem manajemen PNS berbasis merit.

Lahirnya Undang-Undang Nomor 5 Tahun 2014 tentang Aparatur Sipil Negara (ASN) merupakan pintu utama sebagai landasan untuk melakukan reformasi birokrasi. Dalam Pasal 12 UU ASN disebutkan bahwa pegawai ASN berperan sebagai perencana, pelaksana, dan pengawas penyelenggaraan tugas umum pemerintahan dan pembangunan nasional melalui pelaksanaan kebijakan dan pelayanan publik yang profesional, bebas dari intervensi politik, serta bersih dari praktik Korupsi, Kolusi, dan Nepotisme (KKN). Menurut Effendi (2010:119) reformasi birokrasi harus diarahkan untuk menciptakan sistem manajemen kepegawaian PNS yang diselenggarakan berdasarkan sistem meritokrasi. Dalam sistem merit manajemen PNS hanya menekankan profesionalisme pada pengisian jabatan-jabatan dalam birokrasi pemerintahan, dimana apabila ada seorang pegawai yang mempunyai kompetensi dan keahlian sesuai dengan yang dibutuhkan pada suatu jabatan, bisa diangkat untuk menduduki jabatan tersebut (Thoha, 2003:107). Untuk mewujudkan sistem manajemen PNS berbasis merit, setiap instansi pemerintah wajib melakukan penataan pegawai, perbaikan tatalaksana, dan merampingkan organisasi pemerintahan. Dalam melakukan penataan pegawai setiap instansi pemerintah wajib menyusun kebutuhan jumlah dan jenis jabatan PNS berdasarkan analisis jabatan dan analisis beban kerja. Penyusunan kebutuhan jumlah dan jenis jabatan PNS dilakukan untuk proyeksi jangka waktu 5 (lima) tahun kedepan yang diperinci per 1 (satu) tahun berdasarkan prioritas kebutuhan sebagaimana tertera dalam road map reformasi birokrasi.

Untuk memenuhi tuntutan reformasi birokrasi, pemerintah telah mengeluarkan dan menerapkan berbagai kebijakan. Langkah yang diambil adalah melaksanakan restrukturisasi organisasi, perbaikan tatalaksana dan penataan pegawai melalui kebijakan moratorium penerimaan PNS di tahun 2011. Restrukturisasi organisasi antara lain dilakukan untuk menggabungkan atau menghapus lembagalembaga dan unit-unit kerja yang fungsinya tumpang tindih atau bahkan sudah tidak sesuai dengan kebutuhan dan perkembangan. Perbaikan tatalaksana dilakukan untuk menyusun dan memperbaiki ulang Standar Operating Procedure (SOP) kerja di masing-masing lembaga pemerintahan agar tidak terjadi miss dan tumpang tindih pekerjaan. Penataan pegawai dilakukan untuk menghitung kembali secara pasti, berapa jumlah PNS yang dibutuhkan serta komposisi dan distribusi diseluruh instansi pemerintah. Untuk melaksanakan kegiatan penataan jumlah dan kebutuhan PNS, restrukturisasi kelembagaan dan tatalaksana, serta anggaran pemerintah dituangkan dalam langkah strategis berupa kebijakan moratorium PNS.

Moratorium tujuannya untuk mereview bezetting dan penataan PNS, rightsizing kelembagaan dan tatalaksana, serta mengatur anggaran (budgeting) pemerintah. Bezetting dan penataan PNS dilakukan untukmenciptakan jumlahideal kebutuhan pegawai baik dari sisi kuantitasmaupun kualitasnya. Rightsizing kelembagaan dilakukan untuk menciptakan organisasi yang sederhana, flate, dan kaya fungsi, dengan memperjelas tatalaksana (business process). Budgeting dilakukan untuk menciptakan komposisi ideal antara jumlah anggaran untuk belanja pegawai dan belanja pembangunan. Kebijakan moratorium penerimaan PNS 2015 akan memprioritaskan pada kegiatan yang sama seperti pada kebijakan moratorium penerimaan PNS sebelumnya di tahun 2011, yaitu melaksanakan kegiatan penataankebutuhan pegawai, kelembagaan dan tatalaksana, serta anggaranbelanja pemerintah. Disinilah dua pokok permasalahan menarik yang dapat dikaji dan dianalisis, mengapa pemerintah mengambil kembali kebijakan moratorium PNSdan faktor apa yang mendasari kebijakan moratorium PN Stersebut? Tujuan kajian ini untuk mengurai pada isu-isu strategis berkaitan dengan analisis bezetting PNS, rightsizing kelembagaan dan perbaikan tatalaksana, serta efisiensi budgeting pemerintah. 


\section{B. METODE PENELITIAN}

Kajian ini merupakan policy research dengan menggunakan pendekatan descriptive analysis terhadap data-data kualitatif dari hasil focus group discussion (FGD) dan studi dokumentasi. Peserta FGD terdiri antara lain Menteri PAN-RB, Sekretaris Menteri PAN-RB, Kepala BKN, Wakil Kepala BKN, Plt Sekretaris Utama BKN, Deputi Kinerja dan Per UU BKN, Deputi INKA BKN, Deputi Pengawasan BKN, Kepala Biro Kepegawaian BKN, Kepala Pusat Assessment Center BKN, Kepala Pusat Pengkajian dan Penelitian BKN, Kepala Pusat Rekrutmen BKN, Kepala Pusat Pembinaan Jabatan ASN BKN. Data primer diperoleh dari hasil FGD berupa catatan, rekaman, dan notulen, sedangkan data sekunder diperoleh dari hasil studi dokumentasi/pustaka seperti jurnal, laporan penelitian/kajian, buku, media masa (cetak dan elektronik), dan peraturan perundang undangan. Lokasi kajian dan pengambilan data dilakukan di Kantor Badan Kepegawaian Negara (BKN) dan Kantor Kementerian Pendayagunaan Aparatur Negara dan Reformasi Birokrasi (Kementerian PAN RB). Pengkajian dilaksanakan padabulan November-Desember 2014. Analisis data menggunakan model yang dikembangkan Milles dan Huberman (1992:16), yaitu melalui tiga jalur kegiatanreduksi data, penyajian dan analisisdata, serta penarikan kesimpulan/verifikasi.

\section{HASIL DAN PEMBAHASAN}

\section{Moratorium PNS}

Moratoriun PNS hakikatnya dalam rangka melakukan penataan pegawai untuk menciptakan pemerintahan yang efektif dan efisien. Menurut Rusli (2014:218) dengan penataan pegawai diharapkan dapat memperbaiki komposisi dan distribusi pegawai dengan indikasi; (1) Terjadinya kesesuaian antara jumlah dan komposisi pegawai dengan kebutuhan masing-masing unit kerja; (2) Terciptanya kesesuaian antara kompetensi yang dimiliki pegawai dengan syarat jabatan; (3) Terdistribusinya pegawai secara proporsional dimasing-masing unit kerja sesuai beban kerjanya; (4) Tersusunnya sistem penggajian yang adil, layak, dan mendorong peningkatan kinerja; (5) Terlaksananya sistem penilaian kinerja yang obyektif.

Kebijakan moratorium PNS pernah dilaksanakan oleh pemerintah sebelumnya di tahun 2011 melalui pemberlakuan Peraturan Bersama Menteri PAN-RB Nomor 02/SPB/M.PAN-RB/8/2011, Menteri Dalam Negeri Nomor 800-632 Tahun 2011, dan Menteri Keuangan Nomor 141/PMK.01/ 2011 tentang Penundaan Sementara Penerimaan Calon Pegawai Negeri Sipil.Dalam masa penundaan sementara (1 September 2011-31 Desember 2012) tersebut, setiap instansi pemerintah baik pusat maupun daerah diwajibkan melakukan penghitungan jumlah kebutuhan PNS yang tepat berdasarkan analisis jabatan dan analisis beban kerjanya. Selain itu, masing-masing instansi pemerintah juga diwajibkan untuk menyusun proyeksi kebutuhan PNS selama lima tahun ke depan. Teknis pelaksanaanya dilakukan secara berkesinambungan dengan sasaran prioritas per tahun secara jelas yang disesuaikan dengan kemampuan keuangan negara, dan hasilnya disampaikan paling lambat pada akhir bulan Juni 2012.

Moratorium PNS merupakan bentuk kebijakan pemerintah untuk menata PNS dengan melakukan penundaan sementara penerimaan PNS di Indonesia (Peraturan Bersama Menteri PANRB, Menteri Dalam Negeri, dan Menteri Keuangan Nomor 02/SPB/M.PAN-RB/8/2011). Dalam rangka pelaksanaan kebijakan moratorium PNS serta mengoptimalkan kinerja organisasi pemerintah dan efisiensi anggaran belanja pegawai, maka perlu dilakukan penataan PNS kelembagaan dan tatataksananya serta perbaikan sistem anggaran pemerintahan. Anggaran pemerintah perlu ditata ulang sesuai semangat reformasi birokrasi yang diprioritaskan pada pendanaan pembangunan untuk kepentingan masyarakat, faktanya dalam anggaran pembangunan jauh lebih kecil dari pada anggaran 
untuk belanja pegawai. Terkait kebijakan moratorium penerimaan PNS berarti akan ada penundaan kembali pelaksanaan proses rekrutmen PNS karena ada ketetapan baru dari pihak pemerintah.

Menurut Brojonegoro moratoriumartinya tidak menambah jumlah pegawai yang baru dan mempertahankan yang ada, artinya gajinya pegawai tiap tahun akan ada penyesuaian, paling tidak untuk mengikuti inflasi (http://www.kemenkeu.go.id). Menurutnya secara rupiah otomatis meningkat tetapi kalau ditambah komponen pensiun pegawai yang juga mengalami peningkatan, otomatis akan sama saja, karena kadang orang lupa kalau dalam unsur belanja pegawai ada unsur pensiun. Lebih lanjut dikatakan Brojonegoro bahwa moratorium PNS yang dilakukan mulai tahun 2015, tidak akan membawa pengaruh yang drastis pada sisi anggaran pemerintah. Hal ini dikarenakan moratorium sifatnya hanya menahan penambahan jumlah pegawai, sementara posisi gaji pegawai tiap tahun akan tetap mengalami penyesuaian mengikuti inflasi. Perhitungan ini sebagai analisa atas isu moratorium PNS yang muncul pada awal pemerintahan Presiden Joko Widodo yang baru berjalan dua bulan.

Kebijakan moratorium PNS jilid II ini yang menarik bahwa pelaksanaan moratorium penerimaan PNS diberlakukan selama kurang lebih lima tahun kedepan. Ini artinya sama dengan satu periode pemerintahannya yang akan berakhir di tahun 2019. Menurut Menteri PAN-RB Yuddi Chrisnandi moratorium dilakukan untuk memberi ruang pada pemerintah dalam mengevaluasi efektifitas jumlah dan kinerja PNS yang sudah ada, namun hal ini masih dikaji tentang berapa sebenarnya rasio yang tepat jumlah birokrat pegawai negeri kita dibandingkan dengan jumlah penduduk, disamping itu moratorium PNS ini akan dipikirkan secara jernih agar segala keputusan yang dilaku-kan dalam proses reformasi birokrasi efisien dan produktif (http://www.republika. co.id). Menteri PAN-RB saat berkunjung dan melakukan FGD dengan para pejabat di lingkungan Kantor Badan Kepegawaian Negara (BKN) pada tanggal 4 November 2014,meminta BKN untuk segera membuat skema moratorium yang paling tepat untuk PNS, skema yang disusun BKN harus berdasarkan pada hasil penelitian dan pengkajian yang dapat dijabarkan secara akademis.

Disampikan Menteri PAN-RB dalam kesempatan itu moratorium PNS kembali diwacanakan karena permasalahan pemborosan keuangan negara dalam APBN yang sebagian besar hanya diperuntukan bagi pembiayaan aparatur negara. Dikatakan sebagai pemborosan karena struktur organisasi pemerintahan dianggap terlalu gemuk sehingga menyebabkan jumlah PNS menjadi sangat banyak, padahal kinerja mereka dinilai masih jauh dari yang diharapkan. Memperhatikan data dari BKN sampai dengan bulan Juni 2014, jumlah PNS mencapai 4.375.009 orang. Sedangkan untuk membiayai belanja pegawai di tahun 2014, Pemerintah Pusat menetapkan sebesar Rp 263,9 triliun atau 18,9 persen dari APBN, belanja barang senilai Rp 201,8 triliun, belanja modal Rp 205,8 triliun serta pembayaran bunga utang Rp 121,2 triliun (http://www.antaranews.com). Kemudian dari sekitar 530 Kabupaten/Kota, 124 daerah telah menganggarkan lebih dari 60 persen APBD untuk belanja pegawainya, bahkan ada satu Pemerintah Daerah yang mencapai 83persen dari APBD-nya hanya digunakan untuk belanja pegawai.

Menteri PAN-RB tidak akan khawatir kekurangan pegawai dengan penerapan moratorium PNS. Padahal kemungkinan selama 5 tahun kedepan terdapat sejumlah PNS memasuki masa pensiun yang tentunya diperlukan pengganti untuk mengisi posisi yang ditinggalkan. Menurut Menteri PANRB tidak semua PNS memasuki masa pensiun secara bersamaan, karena Kementerian PAN-RB telah memperhitungkan berapa jumlah PNS yang akan pensiun dalam kurun waktu lima tahun (http:/ /bisnis.liputan6.com). Menurutnya secara ekstrem jika moratorium benar diterapkan selama 5 tahun kedepan, akan ada 584.000 PNS yang pensiun, dan itu tidak sampai satu juta dari total PNS sekarang yang mencapai 4.320 .000 orang. Lebih lanjut Menteri PAN-RB mengatakan bahwa para pegawai yang berada di bawah kedudukan pensiunan PNS akan naik menggantikan posisinya. 
Oleh karena itu cara lain yang bisa dilakukan adalah mengisi kekosongan tersebut dengan menggeser pegawai dari instansi lain dengan kualifikasi yang sesuai.

Sisi lain dari kebijakan moratorium yang dilaksanakan mulai bulan Januari 2015 menimbulkan banyak tanggapan dari berbagai kalangan yang disikapi dengan pro dan kontra. Kebijakan moratorium PNS sebelumnya telah dilakukan oleh pemerintahan Presiden Susilo Bambang Yudoyono di tahun 2011 yang direncanakan diulang kembali oleh pemerintahan Presiden Joko Widodo pada masa pemerintahannya. Kebijakan ini apabila benar maka akan sedikit berdampak negatif, mengingat untuk melakukan penataan kembali PNS membutuhkan biaya yang tidak sedikit. Dilihat dari program pemerintah berkelanjutan, kebijakan ini menunjukan tidak ada konsistensi yang jelas secara periodik antara pemerintahan sebelumnya dengan pemerintahan yang melanjutkan. Seharusnya program dan keijakan pemerintah berlangsung secara berkesinambungan secara jelas, sehingga hasilnya akan bermanfaat bagi masyarakat. Pemerintah sebaiknya mempelajari atau mengevaluasi kembali kebijakan moratorium PNS sebelumnya secara mendalam, baru menentukan opsi perlu dilanjutkan atau tidak.

Ketua Komisi Aparatur Sipil Negara (KASN) Sofian Effendi menyatakan tidak setuju dengan rencana pemerintah yang akan melakukan moratorium penerimaan calon PNS, menurutnya pelayanan publik di Indonesia masih buruk di bawah standar minimal sehingga kurangnya PNS akan memengaruhi kualitas pelayanan (Kompas, 12/11/2014). Lebih lanjut Sofian Effendi mengatakan bahwa standar pelayanan publik di negara-negara yang tergabung dalam Organisasi untuk Kerjasama Ekonomi dan Pembangunan (OECD) adalah 84 orang PNS per 1.000 penduduk. Artinya setiap 12 orang penduduk dilayani 1 PNS. Menurut-nya di Indonesia berada di bawah standar minimal dengan pelayanan publik 19 orang PNS per 1.000 penduduk. Apabila pemerintah benar-benar merealisasikan moratorium perekrutan PNS ke depan, maka berdampak besar bagi penyelenggaraan pelayanan publik. Kalau 5 tahun moratorium, kita hanya akan punya 10 orang PNS per 1.000 penduduk, jadi 1 PNS melayani 100 penduduk, karenanya pelayanan publik kita akan semakin jelek. Dengan kondisi tersebut, maka sangat sulit bagi Indonesia untuk mengejar kualitas pelayanan publik setara Singapura dan Malaysia.

Kerangka kajian moratorium PNS hakikatnya untuk memberikan peluang kepada seluruh instansi pemerintah melakukan evaluasi pada aspek penataan SDM PNS, kelembagaan, tatalaksana, dan anggaran belanjanya. Penataan PNS dengan memetakan kondisi PNS secara keseluruhan, sehingga dapat memberikan informasi secara jelas terhadap jumlah/kebutuhan, kualitas/kompetensi, dan penyebaran/penempatan. Pemetaan bezettingkebutuhan pegawai dilakukan melalui tahapan penyusunan peta jabatan, analisis jabatan, analisis beban kerja, dan menyusunan proyeksi kebutuhan 5 tahun ke depan yang diperinci per tahun. Penataan kelembagaan dengan menciptakan rightsizing yang kaya fungsi dengan menciptakan sistem flat. Tatalaksana dengan menyempurnakan Standard Operating Procedure (SOP) melalui pemanfaatan teknologi informasi, sehingga dapat meningkatkan efisiensi dan mengurangi jumlah PNS. Budgeting dengan menyusun komposisi ideal antara jumlah anggaran belanja PNS dengan belanja pembangunan. Adapun kerangka pikir kajian moratorium PNS sebagaimana tertera pada Gambar 1. 


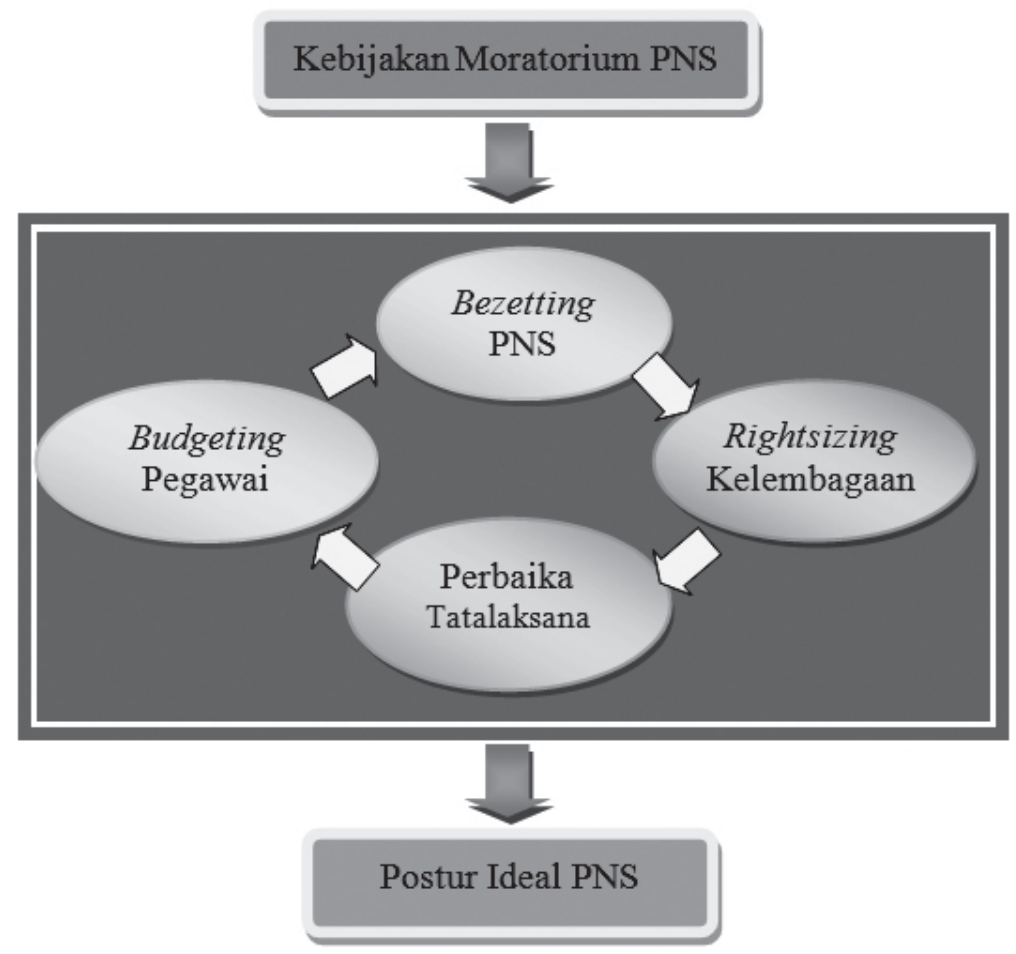

Gambar 1.

Kerangka Pikir Kebijakan Moratorium PNS

\section{BezettingPNS}

Persediaan (bezetting) pegawai merupakan jumlah pegawai yang dimiliki oleh suatu unit kerja pada saat ini (KepMenPAN KEP/75/M.PAN/7/2004). Perhitungan kebutuhan pegawai dapat dilakukan dengan melakukan analisis kebutuhan pegawai. Menurut Morrison (2001:27) bahwa kebutuhan (need) diartikan sebagai kesenjangan antara apa yang diharapkan dengan kondisi yang sebenarnya, keinginan adalah harapan ke depan atau cita-cita yang terkait dengan pemecahan terhadap suatu masalah, sedangkan analisis kebutuhan adalah alat untuk mengidentifikasi masalah guna menentukan tindakan yang tepat. Analisis kebutuhan pegawaiadalah proses yang dilakukan secara logik, teratur, dan berkesinambungan untuk mengetahui jumlah dan kualitas pegawai yang diperlukan berdasarkan beban kerja. Sedangkan analisis kebutuhan PNS merupakan proses perhitungan secara logis dan teratur yang ditentukan untuk menentukan jumlah PNS yang diperlukan agar mampu melaksanakan tugasnya secara berdayaguna, berhasil guna dan berkelanjutan.

Kebutuhan formasi PNS harus ditetakan berdasarkan jumlah dan susunan pangkat PNS yang diperlukan dalam suatu satuan organisasi negara untuk mampu melaksanakan tugas pokok dalam jangka waktu tertentu. Tahapan menghitung formasi PNS melalui analisis jabatan, memperkirakan persedian pegawai, menghitung kebutuhan pegawai, serta menghitung keseimbangan persediaan dan kebutuhan pegawai.Kegiatan analisis jabatan dilakukan untuk menghasilkan informasi jabatan dalam bentuk uraian jabatan dan peta jabatan. Untuk itu guna menciptakan komposisi dan kualifikasi PNS yang ideal perlu adanya perencanaan pegawai dalam manajemen PNS. Perencanaan SDM menurut Sherman dan Bohlander adalah merupakan proses meng-antisipasi dan membuat keputusan untuk mengatur arus gerakan tenaga kerja ke dalam, di dalam, dan keluar organisasi (Nawawi, 2005:137).

Dalam menetapkan formasi PNS perlu memperhatikan hal-hal sebagai berikut; jumlah PNS (bezetting) yang ada, jumlah PNS yang naik pangkat, jumlah PNS yang berhenti, pensiun, atau 
meninggal dunia, serta kebutuhan PNS menurut jabatan dan pendidikan/jurusannya (http:// sdm.ugm.ac.id). Analisis kebutuhan pegawai diinstansi pemerintah merupakan dasar bagi penyusunan formasi PNS. Analisis kebutuhan PNSdapat diperoleh melalui kegiatan analisis jabatan, yang merupakan kegiatan mengumpulkan, menilai, dan mengorganisasikan informasi tentang jabatan PNS. Sedangkan analisis jabatan PNS merupakan proses penyelidikan yang sistematis untuk memperoleh informasi mengenai pekerjaan (job) dan pekerjaan (job holder) PNS. Informasi itu mencakup tugas-tugas yang dilaksanakan dan kualifikasi atau persyaratan yang diperlukan dalam pelaksanaan pekerjaan-pekerjaan yang ada di dalam instansi pemerintah. Berikut ini disajikan hasil penghitungan jumlah kebutuhan PNS pada instansi pusat dan daerah serta hasil verifikasi dan validasi atas hasil penghitungan jumlah kebutuhan PNS (LAKIP BKN, 2012).

Tabel 2.

Hasil Penghitungan Jumlah Kebutuhan PNS pada Instansi Pusat

\begin{tabular}{|c|c|c|c|c|c|c|c|}
\hline \multirow[b]{2}{*}{ Jenis Data } & \multirow[b]{2}{*}{ Struktural } & \multicolumn{5}{|c|}{ Non Struktural } & \multirow[b]{2}{*}{ Total PNS } \\
\hline & & JFU & JFT Dosen & $\begin{array}{l}\text { JFT Tng } \\
\text { Kesehatan }\end{array}$ & $\begin{array}{c}\text { JFT } \\
\text { Lainnya }\end{array}$ & $\begin{array}{c}\text { Total JFU } \\
\text { dan JFT }\end{array}$ & \\
\hline 1 & 2 & 3 & 4 & 5 & 6 & 7 & 8 \\
\hline Bezetting & 95,580 & 510,113 & 183,062 & 109,901 & 36,607 & 839,683 & 935,263 \\
\hline \begin{tabular}{|c} 
Hasil \\
Penghitunga \\
$\mathrm{n}$ \\
Instansi \\
Pusat
\end{tabular} & 115,752 & 421,329 & 186,378 & 373,738 & 104,203 & $1,085,648$ & $1,201,400$ \\
\hline $\begin{array}{c}\text { Verifikasi } \\
\text { BKN }\end{array}$ & 115,752 & 300,802 & 186,378 & 274,034 & 53,939 & 815,153 & 930,905 \\
\hline $\begin{array}{l}\text { Kelebihan/ } \\
\text { Kekurangan }\end{array}$ & $-20,172$ & $+209,311$ & $-3,316$ & $-164,133$ & $-17,332$ & $+24,530$ & $+4,358$ \\
\hline
\end{tabular}

Sumber: Badan Kepegawaian Negara (2013 :33).

Tabel 2 mencerminkan bahwa bezetting pada jabatan struktural sejumlah 95.580, sedangkan hasil penghitungan kebutuhan baik yang dilakukan oleh instansi pusat maupun oleh BKN sejumlah 115.752 sehingga kekurangan pegawai sebanyak 20,172 pejabat struktural. Untuk bezetting pada jabatan fungsional umum (JFU) sejumlah 510.113, sedangkan hasil penghitungan (verifikasi) yang dilakukan oleh BKN sejumlah 300.802, sehingga terdapat selisih kelebihan pegawai sejumlah 209.311. Sedangkan untuk jabatan fungsional tertentu (JFT) khususnya bagi tenaga dosen dengan bezetting sejumlah 183,062, hasil verifikasi yang dilakukan oleh BKN sejumlah 186,378, sehingga terdapat kekurangan pegawai sejumlah 3.316. Untuk JFT khususnya bagi tenaga kesehatan dengan bezetting sejumlah 109.901, sedangkan hasil verifikasi yang dilakukan oleh BKN sejumlah 274.034, sehingga terdapatkekurangan pegawai sejumlah 164.133. Untuk JFT lainnya dengan bezetting sejumlah 36.607 pegawai, hasil verifikasi yang dilakukanoleh BKN sejumlah 53.939 pegawai, sehingga terdapat kekurangan pegawai sejumlah 17.332.

Adapun jumlah total PNS untuk jabatan non struktural pada instansi pusat adalah sejumlah 839.683 pegawai, sedangkan jumlah total hasil verifikasi kebutuhan tenaga non struktural yang dilakukan oleh BKN sejumlah 815.153 pegawai. Hal ini menunjukan tenaga non struktural terdapat kelebihan pegawai sejumlah 24.530 (akumulasi dari kelebihan ataupun kekurangan jumlah pegawai per jenis jabatan non struktural). Dengan demikian secara umum terlihat bahwa pada instansi pusat terdapat 
kelebihan pegawai sejumlah 4.358 (bezetting = 935.263 dikurangi kebutuhan =930,905). Angka kelebihan tersebut merupakan akumulasi dari kelebihan ataupun kekurangan pegawai pada setiap jenis jabatan (struktural dan non struktural) dengan pertimbangan apabila dilakukan kebijakan redistribusi/ reposisi atau promosi jabatan serta pengalihan fungsi yaitu pengangkatan pegawai yang ada dari JFU menjadi JFT sesuai dengan kompetensi yang disyaratkan dalam jabatan tersebut.

Penghitungan jumlah kebutuhan PNS instansi daerah dari 524 instansi daerah yang sudah menyampaikan hasil penghitungan kebutuhan pegawai adalah sebanyak 495 instansi, yang telah dilakukan verifikasi sebanyak 489 instansi dan yang belum di verifikasi sebanyak enam instansi dikarenakan data tidak lengkap. Sementara yang belum menyampaikan sebanyak 29 instansi sehingga total yang belum diverifikasi karena data tidak lengkap dan yang belum menyampaikan laporan hasil penghitungan kebutuhan pegawai adalah sebanyak 35 instansi. Tabel 3 mencerminkan bahwa bezetting pada tenaga struktural sejumlah 346.306, sedangkan hasil penghitungan kebutuhan yang dilakukan oleh BKN sejumlah 398.930, sehingga kekurangan pegawai sebanyak 52.624 pejabat struktural. Untuk bezetting pada JFU sejumlah 1.058.502, sedangkan hasil penghitungan (verifikasi) yang dilakukan oleh BKN sejumlah 829.319, sehingga terdapat selisih kelebihan pegawai sejumlah 229.183. Sedangkan untuk JFT khususnya pada tenaga guru dengan bezetting sejumlah 1.622.168, sedangkan hasil verifikasi yang dilakukan oleh BKN sejumlah 1.765.743, sehingga terdapat kekurangan pegawai sejumlah 143.575.

Tabel 3.

HasilPenghitunganJumlahKebutuhan PNS pada Instansi Daerah

\begin{tabular}{|c|c|c|c|c|c|c|c|}
\hline Jenis Data & Struktural & $\begin{array}{c}\text { Non } \\
\text { Struktural }\end{array}$ & Guru & \multicolumn{2}{|c|}{ Tenaga Yankes } & Kotal & Ket \\
\hline$I$ & 2 & 3 & 4 & 5 & 6 & 7 & 8 \\
\hline Bezetting & 346.306 & 1.058 .502 & 1.622 .168 & 309.191 & 85.926 & 3.422 .093 & $\begin{array}{c}489 \\
\text { Instansi }\end{array}$ \\
\hline $\begin{array}{c}\text { Hasil } \\
\text { Penghitungan } \\
\text { Instansi } \\
\text { Daerah }\end{array}$ & 399.685 & 1.286 .141 & 2.084 .008 & 464.048 & 180.108 & 4.413 .990 & $\begin{array}{c}489 \\
\text { Instansi }\end{array}$ \\
\hline $\begin{array}{c}\text { Verifikasi } \\
\text { BKN }\end{array}$ & 398.930 & 829.319 & 1.765 .743 & 393.118 & 164.894 & 3.552 .004 & $\begin{array}{c}489 \\
\text { Instansi }\end{array}$ \\
\hline $\begin{array}{c}\text { Kelebihan/ } \\
\text { Kekurangan }\end{array}$ & -52.624 & +229.183 & -143.575 & -83.927 & -78.968 & -129.911 & \\
\hline
\end{tabular}

Sumber:Badan Kepegawaian Negara (2013 : 34).

Untuk JFT khususnya pada tenaga kesehatan dengan bezetting sejumlah 309.191, sedangkan hasil verifikasi yang dilakukan oleh BKN sejumlah 393.118, sehingga terdapat kekurangan pegawai sejumlah 83.927. Untuk tenaga non kesehatan dengan bezetting sejumlah 85.926, sedangkan hasil verifikasi yang dilakukan oleh BKN sejumlah 164.894, sehingga terdapat kekurangan pegawai sejumlah 78.968. Dengan demikian dapat dilihat bahwa bezetting pegawai dari 489 instansi daerah adalah sejumlah 3.422.093. Sedangkan dari hasil verifikasi yang dilakukan oleh BKN kebutuhan pegawai instansi daerah tersebut sejumlah 3.552.004, sehingga terdapat kekurangan sebanyak 129.911 pegawai. Angka kekurangan tersebut merupakan akumulasi dari angka kelebihan ataupun 
kekurangan pegawai pada setiap jenis jabatan, dengan pertimbangan apabila dilakukan kebijakan redistribusi/reposisi atau promosi jabatan serta pengalihan fungsi yaitu pengangkatan pegawai yang ada dari jabatan fungsional umum menjadi jabatan fungsional tertentu sesuai dengan kompetensi yang disyaratkan dalam jabatan tersebut.

Berdasarkan hasil penghitungan kebutuhan PNS instansi pusat dan daerah tersebut, maka dapat dijelaskan bahwa bezetting PNS sejumlah 4.357.356 (Instansi Pusat=935.263 dan Instansi Daerah =3.422.093) dari 565 instansi (Instansi Pusat=76 dan Instansi Daerah=489). Sedangkan hasil penghitungan PNS yang dilakukan oleh instansi sejumlah 5.615.390 (Instansi Pusat=1.201.400 dan Instansi Daerah=4.413.990) dari 565 instansi. Hasil verifikasi dan validasi BKN berdasarkan peraturan yang berlaku dapat disimpulkan bahwa jumlah kebutuhan PNS adalah 4.482.909 (Instansi Pusat=930.905 dan Instansi Daerah=3.552.004). Sehingga secara keseluruhan terdapat kekurangan jumlah PNS sebanyak 125.553 (4.482.909 dikurangi 4.357.356) dari 565 instansi. Untuk penghitungan jumlah kebutuhan PNS yang tepat pada seluruh instansi baik instansi pusat maupun instansi daerah jika menggunakan parameter luas wilayah, jumlah penduduk, dan jumlah PNS maka dapat diproyeksikan sejumlah 4.650.000 pegawai. Hasil verifikasi data dan validasi hasil penghitungan jumlah kebutuhan PNS yang dilakukan oleh BKN, digunakan sebagai pengendalipenetapan tambahan formasi CPNS, menjamin efisiensi anggaran belanja pegawai serta dalam rangka terciptanya perencanaan kepegawaian yang efektif dan efisien.

Memperhatikan kondisi riil hingga sampai saat ini bahwa jumlah kebutuhan dan distribusi PNS masih belum proporsional, hal ini dapat dilihat pada komposisi antara jabatan teknis dengan tenaga administratif yang belum seimbang, mismatch antara kompetensi PNS dengan persyaratan yang dibutuhkan jabatan, disparitas (kesenjangan) antara kebutuhan PNS dengan ketersediaan pegawai. Penghitungan jumlah kebutuhan PNS melalui program penataan dan pemetaan kebutuhan PNS yang didasarkan pada analisis perhitungan beban kerja sampai saat ini juga belum sepenuhnya berhasil dengan baik, sehingga memerlukan perbaikan lebih lanjut. Peta jabatan dan proyeksi kebutuhan pegawai lima tahun ke depan yang dibuat per tahun sebagai salah satu persyaratan untuk mendapatkan formasi PNS juga belum dibuat secara nyata oleh sebagian besar instansi pemerintah, khususnya pada Pemerintah Daerah. Disamping itu keseimbangan anggaran bagi pemerintahan juga masih menjadi permasalahan serius tersendiri, dimana masing-masing instansi pemerintahan masih menempatkan belanja pegawai lebih besar dari pada belanja pembangunannya.

\section{Rightsizing Kelembagaan}

Organisasi merupakan bentuk lembaga yang dominan dalam bermasyarakat dan bernegara, dimana suatu tujuan-tujuan individu dalam masyarakat tersebut untuk mencapai tujuannya selalu menggunakan sarana yang namanya lembaga atau organiasi. Birokrasi pemerintahan sebagaimana organisasi lainya yang didalamnya terdapat struktur, budaya, dan teknologi, tidak dapat lepas dari pengaruh lingkungan strategis. Struktur organisasi merupakan sistem formal tentang hubungan tugas dan wewenang yang mengendalikan bagaimana tiap individu bekerjasama dan mengelola sumberdaya yang ada untuk mewujudkan tujuan organisasi Wisnu (2005:10). Restrukturisasi atau rightsizing kelembagaan dilakukan untuk menyehatkan instansi pemerintah agar dapat beroperasi secara efisien, efektif, dan produktif. Restrukturisasi lembaga pemerintah bertujuan untuk meningkatkan kinerja dan nilai pemerintah dalam memberikan manfaat kepada negara serta menghasilkan produk dan layanan masyarakat yang kompetitif.

Program reformasi birokrasi pemerintahan menekankan pada prioritas penataan SDM PNS, kelembagaan, dan tata laksana yang dituangkan dalam agenda reformasi birokrasi nasional. Program 
rightsizing kelembagaan pemerintahan merupakan program utama dari program penataan kembali PNS dengan cara pemetaan secara lebih tajam, kemudian dilakukan konsolidasi (regrouping) untuk mencapai jumlah dan skala usaha penataan PNSyang lebih ideal. Program dilakukan berdasarkan pertimbangan urgensi bagi efektifitas kinerja birokrasi pemerintahan sebagai pelayan publik di masingmasing institusi pemerintahan.Untuk menyukseskan program reformasi birokrasi tidak sekadar memperbaiki remunerasi semata, tetapi sebagai upaya merasionalisasi struktur dan organ penyelenggara pemerintahan. Reformasi kelembagaan birokrasi bukan sekadar program insidentil yang hanya menyelesaikan persoalan di permukaan saja, tetapi harus didorong pada perbaikan tatanan lembaga yang lebih efektif dan efisien.

Dalam rangka pelaksanaan pendayagunaan aparatur PNS, di Tahun 2011 pemerintah mengeluarkan keputusan bersamaMenteri PAN RB, Menteri Dalam Negeri, dan Menteri Keuangan tentang moraturium penerimaan PNS. Dengan moratorium PNS diharapkan semua instansi pemerintah melakukan penundaan penerimaan PNS tujuannya untuk menata kembali pegawai di masing-masing unit kerjanya. Sedangkan dalam penyelesaian penataan PNS dihimbau kepada instansi pemerintah untuk melakukan restrukturisasi kelembagaannya, tujuannya untuk menciptakan sinkronisasi menuju efektivitas organisasi pemerintahan. Restrukturisasi dan penataan PNS sangat diperlukan dalam proses mewujudkan tata pengolaan pemerintahan yang baik (good governance). Banyaknya lembaga negara disamping berdampak pada tingginya belanja rutin pegawai, tidak bisa mewujudkan efisiensinya penyelenggaraan pemerintahan.

Salah satu program moratorium PNS melakukan restrukturisasi lembaga pemerintahan, tujuannya untuk mengevaluasi dan memastikan bahwa semua lembaga pemerintah sudah berjalan efektif dan efisien sesuai fungsinya, sehingga organisasi pemerintah menjadi tepat fungsi dan tepat ukuran (rightsizing).Target yang ingin dicapai dari rightsizing lembaga pemerintahan adalah; (a) Menurunnya tumpang tindih tugas pokok dan fungsi antar Kementerian/Lembaga/Pemda;(b) Meningkatnya kapasitas lembaga dalam melaksanakan tugaspokok dan fungsi Kementerian/ Lembaga/ Pemda. Penataan tatalaksana bertujuan meningkatkan efisiensi dan efektivitasbisnis proses dan mekanisme kerja/prosedur dalam system manajemen pemerintahan. Adapun target yang ingin dicapai program ini adalah; (a) Meningkatnya penggunaan teknologi informasi dalam proses penyelenggaraan manajemen pemerintahan;(b) Meningkatnya efisiensi dan efektivitas manajemen pemerintahan.

Adapun ruang lingkup restrukturisasi lembaga pemerintah adalah; pertama, restrukturisasi sektoral yang pelaksanaannya disesuaikan dengan kebijakan sektor dan/atau Peraturan Perundangundangan.Kedua; restrukturisasi ekternal yang meliputi peningkatan intensitas persaingan dengan organisasi lainnya (BUMN dan swasta), penataan hubungan fungsional antar organisasi pemerintahan,serta menetapkan arah dalam rangka pelaksanaan kewajiban pelayanan publik. Ketiga, restrukturisasi internal yang mencakup keuangan, organisasi/manajemen, dan operasional pemerintahan. Program restrukturisasi sektoral pada intinya adalah untuk mencapai jumlah dan skala usaha pemerintah yang ideal yang merupakan kelanjutan dan penajaman dari program rightsizing dan penataan PNS sebagaimana yang terdapat di dalam master plan arah reformasi birokrasi 2010-2025 dan road map Tahun 2010-2014. Restrukturisasi lembaga pemerintah dan tatalaksana harus dilaksanakan dengan ukuran yang jelas, dimana organisasi harus disesuaikan dengan tugastugas pemerintahan yang dibebankan pada Kementerian/Lembaga $(\mathrm{K} / \mathrm{L})$ dan tidak ada tumpang tindih urusan antar K/L.

Hasil kajian Pusat Kajian Kinerja Kelembagaan LAN (2013:114) menunjukkan bahwa untuk kelembagaan Pemerintah Pusat belum mencerminkan kelembagaan yang tepat ukur (rightsize) sesuai dengan kebutuhan dan beban kerja yang ideal. Sedangkan menurut Thoha terdapat batas maksimal 
kemampuan atasan mengontrol bawahan dimana dalam teori organisasi kemampuan orang mengontrol orang lain ada batasnya, yaitu hanya lima sampai tujuh orang, artinya dalam membentuk struktur organisasi bawahan yang dikontrol atasan tidak lebih dari tujuh orang atau unit organisasi (Kompas, 24/1/2015). Lebih lanjut dikatakan Thoha bahwa yang terjadi sekarang ini di K/L justru tidak seperti itu, hal ini menurutnya agar K/L konsisten dalam melakukan perampingan. Menurutnya hingga sampai saat ini rightsizing kelembagaan instansi pemerintah masih sebatas pada $13 \mathrm{~K} / \mathrm{L}$ yang ada di Pemerintah Pusat dan minus 21 Kementerian lainnya serta belum menyentuh pada institusi Pemerintahan Daerah, restukturisasi dari program ini sekitar 250 pejabat Eselon I(Pimpinan Tinggi) hingga Eselon IV (Pengawas) akan dihapus.

Programpenataanlembagadiharapkan bisamendorong mobilitas antara PNS Pemerintah Pusat dan Daerah serta sebaliknya antar PNS Pemerintah Daerah dan PNS Pemerintah Pusat. Target yang ingindicapai melalui program ini adalah; (a) Meningkatnya ketaatan terhadap pengeloaan PNS; (b) Meningkatnya transparansi dan akuntabilitas pengelolaan PNS; (c) Meningkatnya disiplin PNS; (d) Meningkatnya efektivitas manajemen PNS; (e) Meningkatnya profesionalisme PNS. Program reformasi birokrasi seutuhnya diarahkan pada perubahan masyarakat, termasuk didalamnya masyarakat birokrasi (pemerintahan) dalam melakukan perubahan (changes) ke arah kemajuan (improvement). Berdasarkan hasil kajian dari Pusat Kajian Kinerja Kelembagaan LAN (2013:23) bahwa jumlah K/L dari masa pemerintahan Presiden Soekarno sampai pemerintahan Presiden Abdurrahman Wachid mengalami penurunan, namun mulai pemerintahan Presiden Megawati menunjukan ada peningkatan (lihat Tabel 4).

Tabel 4.

Kelembagaan Pemerintah Pusat Dari Waktu Ke Waktu

\begin{tabular}{|l|c|c|c|c|c|}
\hline \multirow{2}{*}{\multicolumn{1}{c|}{ Kabinet }} & \multicolumn{5}{c|}{ Kementerian } \\
\cline { 2 - 6 } & Dep/Kem & Menko & Meneg & $\begin{array}{c}\text { Menmud } \\
\text { Wamen }\end{array}$ & Total \\
\hline Kabinet Ampera I & 24 & 6 & & & \\
\hline Kabinet Ampera II & 21 & & 2 & & \\
\hline Kabinet Pembangunan I & 25 & 2 & 5 & & 25 \\
\hline Kabinet Pembangunan II & 21 & 2 & 2 & & 21 \\
\hline Kabinet Pembangunan III & 30 & 3 & 3 & 6 & 30 \\
\hline Kabinet Pembangunan IV & 37 & 3 & 8 & 5 & 37 \\
\hline Kabinet Pembangunan V & 38 & 3 & 8 & 6 & 38 \\
\hline Kabinet Pembangunan VI & 39 & 5 & 10 & & 39 \\
\hline Kabinet Pembangunan VII & 34 & 4 & 10 & & 34 \\
\hline Kabinet Reformasi & 20 & 4 & 12 & & 36 \\
Pembangunan & 16 & 3 & 15 & & 34 \\
\hline Kabinet Persatuan Nasional & 17 & 3 & 10 & & 30 \\
\hline Kabinet Gotong Royong & 20 & 4 & 10 & 3 & 34 \\
\hline Kabinet Indonesia Bersatu I & 31 & 5 & & 20 & 34 \\
\hline Kabinet Indonesia Bersatu II & & & &
\end{tabular}

Sumber: Lembaga Administrasi Negara (2013).

Sedangkan bersasarkan data dari Kementerian PAN dan RB sebagaimana disampaian Azwar Abubakar di tahun 2013 ada enamK/L atas inisiatif sendiri mengajukan permohonan restrukturisasi organisasi, yaitu Badan Tenaga Nuklir Nasional (Batan), Badan Pusat Statistik(BPS), Kementerian Perumahan Rakyat (Kemenpera), Lembaga Ilmu Pengetahuan Indonesia (LIPI), Badan 
Kependudukan dan Keluarga Berencana Nasional (BKKBN), serta Kementerian BUMN (http:// www.indonesia.go.id). Menteri PAN RB menegaskan bahwa pemerintah akan terus melakukan perampingan organisasi K/L dan ditargetkan dalam bulan November 2013 perampingan organisasi $16 \mathrm{~K} / \mathrm{L}$ bisa diselesaikan. Menurutnya sebelumnya sudah diterbitkan Peraturan Presiden terkait perampingan organisasi, yaitu untuk Kementerian PAN RB yang jumlah Deputinya dari 6 (enam) menjadi 4 (empat), Badan Kepegawaian Negara (BKN), Lembaga Administrasi Negara (LAN), dan Kementerian BUMN tinggal tiga Deputi, sementara itu Tim Restrukturisasi juga telah memaparkan hasil audit konsultan untuk tiga K/L, yaitu Kementerian Pertanian, Kementerian Dalam Negeri, dan Arsip Nasional Republik Indonesia (ANRI), sedangkan audit untuk sepuluh instansi masih berjalan.

\section{BudgetingBelanja PNS}

Budgeting atau anggaran merupakan suatu rencana yang disusun secara sistematis dalam bentuk angka dan dinyatakan dalam unit moneter yang meliputi seluruh kegiatan organisasi untuk jangka waktu/periode tertentu dimasa yang akan datang. Oleh karena rencana yang disusun dinyatakan dalam bentuk unit moneter, maka anggaran seringkali disebut juga dengan rencana keuangan. Dalam anggaran, satuan kegiatan dan satuan uang menempati posisi penting dalam arti segala kegiatan akan dikuantifikasikan dalam satuan uang, sehingga dapat diukur pencapaian efisiensi dan efektivitas dari kegiatan yang dilakukan. Dengan penyusunan anggaran, usaha-usaha organisasi akan lebih banyak berhasil apabila ditunjang oleh kebijaksanaan-kebijaksanaan yang terarah dan dibantu oleh perencanaan-perencanaan yang matang. Orgaisasi yang berkecenderungan memandang ke depan, akan selalu memikirkan apa yang mungkin dilakukannya pada masa yang akan datang. Sehingga dalam pelaksanaannya, organisasi tersebut tinggal berpegangan pada semua rencana yang telah disusun sebelumnya.

Moratorium PNS diperlukan sebagai ruang bagi pemerintah untuk berpikir jernih mengevaluasi jalannya proses pengadaan, seleksi, penempatan, serta efisiensi anggaran belanja pegawai. Kebijakan ini dilakukan oleh pemerintah untuk membenahi segala sesuatu terkait dengan penerimaan PNS, termasuk berbagai aturan yang berkaitan dengan kepegawaian dan komposisi belanja daerah, yang saat ini umumnya tidak sehat.Moratorium PNS perlu dilakukan guna melihat postur ideal pendayagunaan aparatur negara secara nasional, sehingga dapat dilihat ideal dan efisiensinya dari segi anggaran negara. Hal ini dikatakan Menteri PAN-RB bahwa total belanja pegawai telah melampaui 40 persen dari total APBN (http://bisnis.liputan6.com). Menurutnya butuh kondisi tenang dan jernih dalam bentuk moratorium untuk memastikan berapa kebutuhan PNSyang pantas dan tepat, dan bisa dibayangkan kalau anggaran negara di tahun 2014 sebesar 2.019 triliun, maka 40 persen saja sudah sekitar Rp 800 triliun.

Data dari Kementerian Keuangan menunjukan bahwa perkembangan belanja pegawai setiap tahunnya mengalami peningkatan. Secara garis besar belanja pegawai terbagi atas 3 (tiga) pos belanja; (1) Gaji danTunjangan yaitu pengeluaran kompensasi yang harus dibayarkan kepada pegawai pemerintah berupa gaji pokok dan berbagai tunjangan yang diterima berkaitan dengan jenis dan sifat pekerjaan yang dilakukan seperti tunjangan keluarga, tunjangan beras, tunjangan struktural dan fungsional, serta tunjangan lainnya bagi aparatur negara; (2) Honorarium, vakasi, lembur, dll yaitu kompensasi yang harus dibayarkan kepada pegawai honorer pemerintah lembur, vakasi, tunjangan khusus, dan berbagai pembiayaan kepegawaian lainnya sesuai dengan peraturan yang berlaku; (3) Kontribusi sosial yaitu manfaat pensiun aparatur negara serta kontribusi pemerintah dalam rangka pelaksanaan jaminan sosial termasuk jaminan kesehatan bagi pegawai yang masih aktif maupun pensiunan. Tabel 5 menunjukan perkembangan dan proyeksi belanja Pemerintah Pusat dalam periode 2001-2014. 
Tabel 5.

Belanja Pegawai Pemerintah PusatTahun 2001-2014 (Triliun Rupiah)

\begin{tabular}{|c|c|c|c|c|c|c|c|c|c|c|c|c|c|c|}
\hline Uraian & 2001 & 2002 & 2003 & 2004 & 2005 & 2006 & 2007 & 2008 & 2009 & 2010 & 2011 & 2012 & 2013 & 2014 \\
\hline $\begin{array}{c}\text { Gaji dan } \\
\text { Tunjangan }\end{array}$ & 18,9 & 19,3 & 22,2 & 31,8 & 33,4 & 43,1 & 50,3 & 67,8 & 70,7 & 81,0 & 91,5 & 102,2 & 114,5 & 121,2 \\
\hline $\begin{array}{c}\text { Honorarium } \\
\text { dan Vakasi }\end{array}$ & 6,6 & 6,8 & 8,9 & 3,8 & 2,2 & 6,4 & 11,5 & 7,8 & 8,5 & 14,4 & 22,4 & 25,8 & 39,4 & 51,1 \\
\hline $\begin{array}{c}\text { Kontribusi } \\
\text { Sosial }\end{array}$ & 13,2 & 13,4 & 16,5 & 19,3 & 18,7 & 23,8 & 28,5 & 373 & 48,5 & 52,8 & 61,8 & 69,9 & 79,0 & 90,7 \\
\hline Total & 38,7 & 39,5 & 47,7 & 55,0 & 54,3 & 73,3 & 90,4 & 112,8 & 127,7 & 148,1 & 175,7 & 197,9 & 233,0 & 263,0 \\
\hline
\end{tabular}

Sumber: Hadi, et al (2014:158).

Sedangkan perkembangan dan proyeksi belanja untuk Pemerintah Daerah dalam periode 2007-2011 juga mengalami peningkatan yang signifikan, khususnya untuk belanja pegawai. Total belanja meningkat sebesar 83 persen dari tahun 2007 sampai tahun 2011 yang kemungkinan besar disebabkan karena makin banyaknya jumlah daerah, disamping alasan logis bertambahnya kebutuhan Pemerintah Daerah. Dari keempat besar jenis belanja tersebut, belanja pegawai, belanja barang/ jasa,dan belanja lainnya meningkat relatif konstan, sementara belanja modal menurun sekitar 8 persen. Sebagian besar belanja daerah digunakan untuk belanja pegawai sebesar 58 persen yang meningkat tajam dibandingkan belanja pegawai tahun sebelumnya sebesar 45 persen. Provinsi Papua Barat memiliki persentase belanja pegawai paling kecil yaitu sebesar persen, sementara Kabupaten Demak mencapai 89 persen yaitu sekitar 2 kali rata-rata belanja pegawai nasional. Berbeda halnya dengan belanja pegawai, belanja modal mengalami penurunan persen yaitu menjadi Rp 106 Triliun di Tahun 2011. Tabel 6 menunjukan jenis belanja Pemerintah Daerah secara rinci dalam bentuk tabel sebagaimana dikutip dari buku Anggaran Pendapatan dan Belanja Pemerintah Daerah (APBD) Tahun 2011.

Tabel 6.

Jenis Belanja Pemerintah Daerah Dalam Kurun Waktu 2007-2011

\begin{tabular}{|l|c|c|c|c|c|c|c|}
\hline \multicolumn{1}{|c|}{$\begin{array}{c}\text { Jenis } \\
\text { Belanja }\end{array}$} & 2007 & 2008 & 2009 & 2010 & 2011 & $\begin{array}{c}\text { Rata- } \\
\text { Rata }\end{array}$ & Persentase \\
\hline Dalam milyar rupiah & 258,986 & 366,951 & 412,413 & 443,565 & 474,135 & 391,210 & 100 \\
\hline Belanja Pegawai & 100,477 & 148,515 & 169,279 & 198,578 & 275,029 & 178,376 & 46 \\
\hline Belanja Barang Jasa & 46,525 & 66,585 & 76,300 & 82,006 & 94,982 & 73,280 & 19 \\
\hline Belanja Modal & 77,477 & 97,866 & 104,614 & 96,170 & 106,207 & 96,467 & 25 \\
\hline Belanja Lainnya & 34,507 & 53,986 & 62,219 & 66,811 & 64,054 & 56,315 & 14 \\
\hline
\end{tabular}

Sumber: Tim (2011:9).

Data lain menunjukan bahwa di tahun 2011 juga terjadi ketimpangan, dimana belanja pegawai jauh lebih besar ketimbang belanja publik atau anggaran yang digunakan untuk pelayanan publik dan pembangunan. Belanja pegawai di 294 kabupaten/kota lebih dari 50 persen APBD. Bahkan di 116 Kabupaten/Kota justru lebih dari 60 persen. Tidak hanya itu, di sejumlah daerah juga ditemukan adanya alokasi belanja pegawai lebih dari 70 persen dari APBD (Kompas, 6 September 2011). Kementerian Keuangan mengungkapkan sejumlah daerah memiliki porsi belanja pegawai mencapai 70-80 persen dari total APBD, padahal, untuk rata-rata seluruh Indonesia hanya mencapai 49-52 
persen (http://www.republika. co.id). Aspek dominan yang menyebabkan membengkaknya belanja pegawai diakibatkan oleh adanya otonomi daerah, dimana muncul pemekaran daerah menjadikan pemerintahan daerah baru yang tentunya membutuhkan pegawai baru pula. Konsekuensinya pemerintah mengalokasikan belanja pegawai baru tersebut untuk membayar gaji dan operasionalnya.

Disamping itu kebijakan yang tidak kalah pentingnya bahwa pemerintah melanjutkan program remunerasi pada K/L pada tahun 2015. Kemudian dalam jangka menengah (periode 2016-2018) kebijakan belanja K/L salah satunya diarahkan untuk mendukung pelaksanaan penyelenggaraan pemerintahan yang efektif dan efisien dengan memperbaiki kesejahteraan aparatur negara dan menampung kebutuhan anggaran remunerasi pada K/L terkait pelaksanaan reformasi birokrasi. Sesuai arah kebijakan serta dalam rangka mendukung pencapaian sasaran strategis dan prioritas pembangunan nasional, penganggaran belanja pegawai dalam APBN 2015 menampung kebutuhan belanja pegawai yang meliputi pembayaran gaji, tunjangan yang melekat pada gaji (termasuk gaji ke-13), uang makan dan lembur, tunjangan lain terkait dengan belanja pegawai termasuk tunjangan kinerja bagi K/L .

Dalam RAPBN tahun 2015 alokasi anggaran program pengelolaan belanja lainnya direncanakan sebesar Rp 86.038,0 miliar, jumlah tersebut termasuk dana penyesuaian pendidikan sebesar Rp 21.244,2 miliar yang akan direalokasi ke K/L. Kebijakan pada program pengelolaan belanja lainnya dalam RAPBN tahun 2015 menampung antara lain; (1) penyediaan dana cadangan untuk kenaikan gaji pokok PNS, TNI, dan POLRI sebesar rata-rata 6,0 persen yang selanjutnya akan direalokasi ke K/L; (2) penyediaan dana cadangan untuk gaji bagi tambahan pegawai baru; (3) penyediaan dana cadangan lainnya yang terkait dengan kebijakan kepegawaian (http:// setagu.net). Data ini memperlihatkan bahwa alokasi anggaran untuk belanja dan operasional aparatur pemerintah (PNS, TNI, POLRI) sangat besar sekali.

Belanja negara dalam RAPBN 2015 mencapai Rp2.019,87 triliun, dari jumlah tersebut Rp1.379,88 triliun diantaranya merupakan belanja Pemerintah Pusatatau sebesar 68,32 persen dari belanja negara. Sedangkan Rp 639,99 triliun lainnya merupakan transfer ke daerah atau sebesar 31,68 persen dari belanja negara. Data ini menunjukan bahwa transfer ke daerah menyedot anggaran yang sangat besar mencapai hampir sepertiga total APBN. Dengan anggaran sebesar itu diharapkan Pemerintah Daerah sanggup memajukan daerahnya, namun ironisnya dana tersebut banyak dipergunakan untuk dana belanja pegawai.Terserapnya belanja pegawai menjadi fenomena yang mengarah pada kurang sehatnya anggaran pemerintahan, khususnya di pemerintah daerah (Naskah Akademik Moratorion PNS, 2014:18). Dampaknya sebagaimana dapat dilihat bersama bahwa pembangunan, khususnya di daerah sangat lamban.

\section{PENUTUP}

Berdasarkan analisis dan pembahasan bahwa kebijakan moratorium PNS yang tahun 2015 merupakan kelanjutan dari kebijakan moratorium pemerintahan sebelumnya yangsifatnya tidak mengulang dari awal. Hal ini mengingat komponen kegiatan moratorium yang dilaksanakan sama, yaitu pada aspek penataan bezetting pegawai, rightsizing kelembagaan dan tatalaksana, serta budgeting pemerintah. Hasil analisis pada bezetting pegawai menunjukan bahwa pegawai secara kuantitas banyak tetapi secara kualitas sedikit, rightsizing kelembagaan belum menyeluruh khususnya pada Pemerintah Daerah dengan tatalaksana yang masih kurang sempurna, budgeting pemerintah belum ideal antara belanja pegawai dengan belanja pembangunan yang komposisinya lebih besar pada belanja pegawai. Rekomendasi kajian ini untukpenataan pegawaidan efektifvitas anggaran; 
1. Penataan pegawai harus dilaksanakan bersamaan dengan rightsizing kelembagaan dan penyempurnaan pada bussines process-nya.

2. Bila kebutuhan PNS di K/L atau daerah telah memadai sebaiknya diterapkan prinsip zero growth atau pun minus growth. Zero growth, diterapkan untuk instansi yangjumlah pegawainya cukup, rasio anggaran belanja pegawai antara 40-50 persen dari APBD (kabupaten/kota), dan 25-30 persen (provinsi). Sedangkan minus growth diterapkan bagi instansi yang berdasarkan hasil analisa beban kerja jumlah pegawainya sudah kelebihan, anggaran belanja pegawai lebih dari 50 persen APBD (untuk kabupaten/kota), dan bagi provinsi yang rasio belanja pegawainya lebih dari 30 persen APBD.

\section{DAFTAR PUSTAKA}

Aditiasari, Dana. (2014). Ini Perbandingan Jumlah PNS RI dengan Negara Tetangga. http:// finance.detik.com/read/2014/09/01/123520/2677733/4/ini-perbandingan-jumlah-pns-ridengan-negara-tetangga. 25 November 2014 (08.33)

Ariyant, Fiki. (2014). DPRSahkan RUU APBN 2015 Jadi UU APBN 2015. http:// bisnis.liputan6.com/read/2111809/dpr-sahkan-ruu-apbn-2015-jadi-uu-apbn-2015. 25 November 2014 (08.11)

Badan Kepegawaian Negara. (2013). Laporan Akuntabilitas Kinerja Instansi Pemerintah Tahun 2013. Jakarta: BKN

Badan Kepegawaian Negara. (2014). Naskah Akademik Kebijakan Moratorium Penerimaan CPNS. Jakarta: BKN

Darto, Mariman. (2014). Peran Organizational Citizenship Behavior (OCB) Dalam Peningkatan Kinerja Individu di Sektor Publik: Sebuah Analisis Teoritis dan Empiris. Jurnal Borneo Administrator Volume 10 Nomor 1 Tahun 2014. Samarinda: PKP2A III LAN

Deil, Siska Amelie F. (2014). Belanja Pegawai Telan 40\% APBN, Moratorium PNS Perlu Dilakukan. http://bisnis. liputan6.com/read/2131684/belanja-pegawai-telan-40-apbnmoratorium-pns-perlu-dilakukan. 25 November 2014 (08.26)

Dir. SDM. (2014). Formasi PNS. http://sdm.ugm.ac.id/new/content/formasi-pns.25 November 2014 (09.55)

Effendi, Sofian. (2010). Reformasi Tata Pemerintahan: Menyiapkan Aparatur Negara Untuk Mendukung Demokratisasi Politik dan Ekonomi Terbuka. Yogyakarta: Gadjah Mada University Press

Fakih, Mansyur. (2014). Yuddy Chrisnandi akan Moratorium CPNS. http://www.republika.co.id/ berita/nasional/politik/14/10/31/neatpy-yuddy-chrisnandi-akan-moratorium-cpns. 24 November 2014 (14.13)

Fina, N. (2014). Moratorium Tidak Pengaruhi Alokasi Belanja Pegawai. http:// www.kemenkeu.go.id/Berita/moratorium-tidak-pengaruhi-alokasi-belanja-pegawai. 24 November 2014 (14.37)

Hadi, Y. Setianto, Didik Kusnain, Heru Wibowo, dan Agus Kuswantoro. (2014). Dasar-Dasar Praktek Penyusunan APBN di Indonesia: Edisi II, Jakarta: Direktorat Jenderal Anggaran, Kementerian Keuangan 
Harjowiryono, Marwanto. (2013). Kemenkeu: Belanja Pegawai Sejumlah Daerah Capai 80 Persen. http://www. republika.co.id/berita/ekonomi/keuangan/13/08/29/msa3mb-kemenkeubelanja-pegawai-sejumlah-daerah-capai-80-persen. 29 November 2014 (07.58)

Humas Kementerian PAN dan RB. (2013). Menteri PAN-RB: 6 K/L Ajukan Restrukturisasi Organisasi.http://www.indonesia.go.id/in/kementerian/kementerian/13409-menteri-pan-rb6-kl-ajukan-restrukturisasi-organisasi. 2 Oktober 2014(11.31)

KBIO. (2014). Kamus Bahasa Indonesia Online. http://kamusbahasaindonesia. org/ moratorium. 29 November 2014 (07.58)

Keputusan MENPAN. KEP/75/M.PAN/7/2004. Tentang Pedoman Perhitungan Kebutuhan Pegawai Berdasarkan Beban Kerja dalam rangka Penyusunan Formasi PNS. Jakarta: Kementerian PAN

Koran Kompas. (2011). Moratorium PNS. 6 September 2011. Halaman 4. Jakarta

Koran Kompas. (2014). Pelayanan Publik Masih Buruk, Moratorium CPNS Dinilai Berisiko. 12 November 2014. Halaman 2. Jakarta

Koran Kompas. (2015). Perampingan Organisasi Disarankan Menyeluruh. 24 Januari 2015. Halaman 4. Jakarta

Lembaga Administrasi Negara. (2013). LaporanAkhirKajian Desain Kelembagaan Pemerintah Pusat (Arsitektur Kelembagaan 2014-2019), Jakarta: LAN

Milles, Mattew B \& Huberman, Michael B. (1992). Analisa Data Kualitatif. Jakarta: Indonesian University Press

Morrison, Gary. R, Ross, Steven M, Kemp, Jerrold. E. (2001). Designing Effective Instruction. Third Edition John Wiley and Sons, inc printed in the USA

Nawawi, Hadari. (2005). Pengembangan Sumber Daya Manusia Untuk Bisnis Yang Kompetitif. Yogyakarta: Gadjah Mada University Press

Nurhaeni, Ismi Dwi H. (2012). Reformasi Kebijakan Sumberdaya Manusia Adil Gender: Harapan Regulasi Affirmative Action. Civil Service Jurnal Kebijakan dan Manajemen PNS Vol 6 Nomor 2 November 2012. Jakarta: Litbang BKN

Peraturan Bersama Menteri Negara Pendayagunaan Aparatur Negara dan Reformasi Birokrasi Nomor 02/SPB/M.PAN-RB/8/2011, Menteri Dalam Negeri Nomor 800-632 Tahun 2011, dan Menteri Keuangan Nomor 141/PMK.01/2011. Tentang Penundaan Sementara Penerimaan Calon Pegawai Negeri Sipil. Jakarta: Kementerian PAN

Robbins, Stephen. J. (1994). Teori Organisasi Struktur, Desain, dan Aplikasi. Jakarta: Arcan

Rusli, Budiman. (2014). Isu Isu Krusial Administrasi Publik Kontemporer. Bandung: Lepsindo

Samsudin, Sadili. (2006). Manajemen Sumber Daya Manusia. Bandung: CV. Pustaka Setia

Satyagraha. (2014). DPR Setujui APBN 2014. http://www.antaranews.com/berita/402097/ dprsetujui-apbn-2014. 24 November 2014 (14.30)

Setagu. (2014). Belanja Pegawai dalam RAPBN 2015. http://setagu.net/belanja-pegawai-dalamrapbn-2015/. 25 November 2014 (09.19) 
Thoha, Miftah. (2003). Birokrasi Dan Politik Di Indonesia. Jakarta: PT Raja Grafindo Persada

Tim. (2011).Anggaran Pendapatan dan Belanja Pemerintah Daerah (APBD) Tahun 2011, Jakarta: Direktorat Jenderal Perimbangan Keuangan, Kementerian Keuangan

Undang-Undang Nomor 5 Tahun 2014. Tentang Aparatur Sipil Negara, Jakarta: BKN

Wisanggeni, Haryo. (2014). Apa Itu Moratorium. https://www.selasar.com/politik/apa-itumoratorium-. 25 November 2014 (08.22)

Wisnu, Dicky. UR dan Nurhasanah, Siti. (2005). Teori Organisasi Struktur dan Desain. Malang: Universitas Muhammadiyah Malang Press 
